\title{
On the naturalization of karma and rebirth
}

\author{
Chien-Te Lin ${ }^{1 *}$ and Wei-Hung Yen ${ }^{2}$
}

\author{
* Correspondence: \\ bhadanta@gmail.com \\ ${ }^{1}$ Institute of Religion and Humanity, \\ Buddhist Tzu Chi University, 67 St. \\ Jiren, 970 Hualien, Taiwan \\ Full list of author information is \\ available at the end of the article
}

\begin{abstract}
Although Buddhism has become increasingly popular in the West, some vital concepts remain abstruse. Naturalistic Buddhism has arisen mainly as an attempt to demystify certain aspects of Buddhist philosophy, with the idea of rebirth being a particular case in point. In this paper we discuss the difficulties of the naturalization of karma, and show that an understanding of karma with rebirth is coherent with the core teachings of the Buddha. We then attempt to clarify the purpose of karma from the standpoint of Mahayana ethics. We argue that the concepts of rebirth and karma were not only taught to encourage virtuous behavior for the sake of future benefit, but also to reinforce the practitioner's commitment to moral discipline. Although Buddhism allows for different perspectives on rebirth from a modern point of view, a reinterpretation of the concept should not focus on rebirth as something to be explained away. Instead, new perspectives can be used as an additional means to enhance moral education and spiritual development.
\end{abstract}

\section{Introduction}

While plenty of opportunities exist these days for cultural discussion, certain views remain incompatible or even outright conflicting. Because Confucianism portrays human nature as being inherently 'good', the idea of original sin as understood in Christianity for example remains elusive to most Chinese. Similarly, the idea of cyclic rebirth or samsāra that forms part of Eastern philosophies such as Hinduism and Buddhism, does not sit well with the Western scientific worldview.

Cultural difference or incompatibility also occurred in ancient China when the Buddhist idea of rebirth was first introduced to China. ${ }^{1}$ Confucian scholar Fen-Chan (范 縝AD. $450 \sim 515)$ keenly debated with Buddhist disciples, including a faithful Buddhist emperor Liang Wu Di (梁武帝AD. 464 549), about whether there is life after death. To Fen-Chan, life is like a sharp knife, and death is like a blunt knife. Just as there is no sharpness outside a knife, so too there is no life outside the body. Buddhism however holds that the rebirth process is like the transference of a flame from one candle to the other. Though one candle ceases to exist, the fire is never extinguished. The initial conflict and eventual consolidation between views of Buddhism and Confucianism (as well as Taoism) has played a significant role in the history of Chinese culture. ${ }^{2}$

In recent years, Western scholars have taken a keen interest in the concept of karma with some comparing karma and rebirth to Christian idea of evil, ${ }^{3}$ while others look for similarities in Western philosophy or discuss the plausibility of karma from a Western viewpoint; ${ }^{4}$ yet others disavow rebirth while accepting karma. ${ }^{5}$

(c) 2015 Lin and Yen. This is an Open Access article distributed under the terms of the Creative Commons Attribution License (http:// creativecommons.org/licenses/by/4.0), which permits unrestricted use, distribution, and reproduction in any medium, provided the original work is properly credited. 
Naturalized karma is advocated mainly through the denial of rebirth. Much interest has arisen recently in naturalized Buddhist theories with Owen Flanagan's book The Bodhisattva Brain being a case in point. Flanagan suggests that a naturalized or demythicized form of Buddhism can serve to spark interest into the subtle philosophical ideas of Buddhism and become worthy of attention by analytical philosophers and scientific naturalists because it is deep. ${ }^{6}$ Stephen Batchelor's recent publications may also be viewed as avocations of Naturalistic Buddhism. ${ }^{7}$ Naturalistic interpretations of Buddhist thoughts such as severing rebirth from karma bring up interesting discussions, however antitheses point to the credibility of the theory of rebirth, providing not only textual testimony but also valid philosophical arguments to justify the legitimacy of rebirth. ${ }^{8}$

Since the concepts of rebirth and karma are so central to Buddhist theory and practice, I hope to offer a plausible perspective on these matters by way of analyzing arguments that aim to exclude rebirth from the Buddhist framework. To this end, I shall take a closer look at "Critical questions towards a naturalized concept of karma in Buddhism" by Dale Wright, a keynote paper presented at an on-line conference on the topic of "Revisioning Karma." ${ }^{\prime 9}$ My intention is not merely to defend the plausibility of rebirth, but also to use the concept of rebirth as presented in the philosophy of Mahayana Buddhism in order to highlight the ways in which it can augment human ethical existence.

\section{Is rebirth merely a supernatural concept in Buddhism?}

We seem to have no choice but to turn to religion when faced with questions such as: Why was I born into this world? What is my purpose on earth? And what happens after death? In the Christian and Muslim framework, belief in God or Allah is what determines whether people will end up in hell or enjoy eternal afterlife in heaven. Eternal damnation is the destiny of the unbeliever. The Buddhist outlook is somewhat different in that each person's actions shape his or her own future existence and ultimately determine into which of the six realms they will take rebirth following death. This means that people who do not believe in God but nonetheless do good deeds during their lives will not necessarily go to hell. The Buddhist theory of karma holds that you are what you do. Even those who don't believe in the Buddha, will reap the rewards in a future life if they do good and avoid all harmful acts. Buddhist karma tells us that positive action results in beneficial reaction, whereas negative action results in unwanted reaction. This is why it is often said that karma follows a person like a shadow.

To some, the hypothesis of karma might seem more consistent with our intuition of moral justice than the theory of eternal salvation. Some therefore believe that the Buddhist theory of karma is more acceptable to contemporary ethical reflection. ${ }^{10}$ Contemporary scholars have however found certain supernatural elements of the theory troublesome. Dale Wright for example proposes a naturalized theory of Buddhist karma, claiming that karma needs to be disconnected from the metaphysics of rebirth in order to allow further development of Buddhist ethics. ${ }^{11}$ But is the concept of rebirth 'supernatural' from a Buddhist perspective?

The majority of Buddhists accept rebirth as an irrefutable truth, and moreover see it as an integral part of their belief system. This is particularly true in Asia. ${ }^{12}$ They would hardly assent to rebirth merely as a metaphysical speculation. Their firm belief in the 
actuality of rebirth is based on well-founded reasoning. For instance, the theory of rebirth, together with karma, explains why we are born differently in this world. It offers insights into the causes of inequality that exists among mankind, and furthermore offers an explanation of why the circumstances of identical twins who are physically alike, having inherited like genes and experienced the same upbringing, yet they may differ greatly in terms of temperament, intellectual capacity and moral disposition. Furthermore, karma and rebirth may account for phenomena such as that of child prodigies. Prior to attempting to separate the theory of rebirth from karma, it would be better to firstly examine those arguments that link the two concepts. In fact, it can perhaps be argued that one of the deficiencies of naturalists is their oversight of refuting views which support the theory of rebirth prior to developing a naturalized concept of karma. $^{13}$

While ordinary human beings may have trouble judging from direct empirical evidence alone whether or not rebirth actually exists, our inability to perceive its workings cannot conclusively rule out the possibility of its existence. Moreover, our inability to discern something presently doesn't mean that it is forever indiscernible. Empirical evidence may not be taken to serve as the only premise worthy of proving the existence of a certain phenomenon. ${ }^{14}$ Besides, we may not have physical evidence for the existence of rebirth, but inasmuch as it is conceivable, it implies that rebirth is more or less reasonable or logical. For example, it seems counterintuitive for the virtuous to die earlier or experience hardship while the wicked enjoy a prosperous life. For the principle of moral equilibrium to work, therefore, some type of survival beyond the present life should be conceivable. It can further be argued that although ordinary people may not have the perceptual faculties to experience the mechanism of rebirth, it does not necessarily mean that past and future incarnations are imperceptible to evolved beings such as the yogis of India who spend a great deal of their lives developing extraordinary faculties. The workings of a cellular phone may be beyond the comprehensions of a tiny ant on the ground, yet that does not mean cellular phones don't exist or that such devices may not be perceived by and indeed utilized by more evolved beings. Nonexperiential claims are not necessarily counter-experiential; that is, that one phenomenon goes beyond our experience doesn't mean that it necessarily contradicts our experiences. ${ }^{15}$

The Dalai Lama likewise suggests the need to distinguish between what is negated through scientific method and what has not been observed through such a method. ${ }^{16}$ That means that 'proving the non-existential' is different from 'current inability to prove the existential. ${ }^{17}$ Disputing rebirth should lie in the later rather than the former. Actually the reason why rebirth seems mystical to people is because we temporarily have no objective and direct method to access it or prove it, but this doesn't imply it should be denied. Besides, the so-called 'supernatural' may be because of our narrow setting of the concept of nature. Rebirth is a concept that is not merely a physical one, but an axiological one similar to the concepts of good and beauty. Once we are able to embrace a wider concept of nature, the so-called 'supernatural' will very much be natural, and there would be no need for any kind of 'naturalization'. It can in fact be argued that naturalization in itself is unnatural.

We all know that the Buddha declined to elaborate on certain metaphysical questions such as whether or not the world is eternal, or whether the world is finite or infinite. 
He discouraged his followers from wasting time and energy on idle speculation and encouraged them to focus instead on their spiritual progress and the actual development of virtue. The Buddhist simile of a man hit by a poisonous arrow illustrates this well. ${ }^{18}$ Now, the question we may want to ask is: was rebirth also seen as a metaphysical subject that the Buddha was reluctant to discuss? Indeed not so. On the contrary, the Buddhist canon contains large sections devoted to this particular topic and as such it is viewed as one of the core theories of Buddhism. ${ }^{19}$ That being so, just how plausible is a view of karma without rebirth?

\section{Is the Buddhist concept of karma possible without rebirth?}

As previously mentioned, naturalists hold that a naturalized concept of karma is better suited for contemporary ethical reflection. Before we delve into this matter however, it seems only sensible to first determine whether it is even possible to naturalize the Buddhist concept of karma. If karma is a doctrine to the effect that the worldly order has a moral order by which all affairs are conducted ethically, i.e. encouraging a fair distribution of punishments and rewards, could such an ethical order be reduced to a natural one?

In philosophy, naturalism is a theory which proposes that everything is a part of the natural world and that everything can indeed be explained within the context of the methodology of the natural sciences, including ethical theories. Naturalistic ethics, therefore, supposes that 'good' or 'right' can be defined through reference to a natural object. This approach aims to prove that ethical statements are empirical or positive and must be understood in terms of the natural propensities of human beings, without mysterious intuitions or divine help. But, some philosophers, such as G. E. Moore (1873 1958) in particular, accuse ethical naturalism of committing what he terms a "naturalistic fallacy." 20

About three centuries ago, David Hume (1711 1776) put forth the idea that "ought" is different from and indeed not derived from "is." ${ }^{21}$ According to this notion, a firm distinction should be drawn between value and fact, between the ethical and the physical. And anyone who attempts to derive ethical statements from factual statements risks falling into the snare of the "naturalistic fallacy." Ethical concepts, therefore, are not natural ones; that is, they are not scientifically observable and not subject to scientific explanation. In the quest for scientific investigations into rebirth from primarily an ethical perspective, naturalists seem to be blurring the distinction between factual description and moral evaluation. That is, natural science is only one method by which we may interpret our life and the universe at large, but it is not the only one way. Science has made undeniable contributions to modern life, yet it has its limitations, particularly with regard to interpreting axiological issues such as the meaning or purpose of life. Science contributes a lot to solve puzzles pertaining to the physical realm but its methods are not suitable for analyzing ethical value. Purely scientific approaches to the human condition are therefore not altogether reliable. We should therefore not look to science to prove or disprove rebirth.

From this viewpoint follows many more questions such as: is karma a natural kind or not; and is the word karma a natural term, an axiological term, or rather a metaphysical term with a supernatural reference? Does karma have non-natural properties? What is the relation between the laws of karma pertaining to morality and natural law? Assuming 
karma is relevant to the evaluation of a certain action as 'good' or 'bad,' we may also wish to ask whether such an evaluation is a natural fact or event? Furthermore, is the pursuit of a naturalized concept of karma in Buddhism an attempt to define ethical terms by way of appealing to natural terms and thus committing the error of a naturalistic fallacy? In attempting to address these questions, the demarcation between fact and value is worthy of consideration prior to proposing a naturalized concept of Buddhist karma.

In Buddhist scripture, the Buddha clearly set forth the existence of both karma and rebirth. We could say in Buddhism, karma is the corollary of rebirth; while rebirth is the corollary of karma. If severed from the doctrine of rebirth, would it still be fitting to consider this new interpretation of karma to correspond with the Buddhist view on karma? It may very well be possible to formulate a naturalized concept of karma within non-Buddhist contexts, yet it remains doubtful whether such a concept could still be considered part of Buddhist theory.

It seems to me that the concept of karma without rebirth is easily tends toward the view of nihilism, and as such violates the very standpoint of the Middle-Way philosophy which is considered by many to be the core teaching of the Buddha. Just as an eternal view (Skt. nitya-drsțit, Pali sassata-ditțhi) holds that the soul exists independently of our mental and physical processes to continue after death indefinitely, so too the view of nihilism holds that nothing follows death. Both are mistaken views (Skt.ucchedadrsți, Pali uccheda-ditthi) to be abandoned by Buddhist practitioners. ${ }^{22}$ Since the theory of the Middle-Way opposes both eternalism and nihilism, rejecting rebirth would create a view of karma which is no longer compatible with the Buddha's core teachings. Although a naturalized concept of karma might well inspire us to see karma in a purely ethical light, such a viewpoint can no longer be considered Buddhist. ${ }^{23}$ It is important to note that, apart from ethical concerns, the Buddhist doctrines of karma and rebirth have also to be understood within the context of spiritual awakening and liberation of suffering, which serves the overriding aim of Buddhism. ${ }^{24}$

\section{Does rebirth have tension with the Buddhist theory of no self?}

The idea of non-self (anätman) or the non-existence of self may sound counterintuitive to some, and it may seem even more bizarre that such a phenomenon can be reborn. For if there is no self, who or what is the entity that is reborn? Is rebirth consistent with the Buddhist theory of no self ${ }^{25}$ This apparent contradiction is however only superficial and can be overcome by gaining a deeper understanding of rebirth.

While the Sanskrit or Pali term samsära is often translated as 'rebirth', these two terms are quite different and we need to be cautious not to confuse or blur the meaning behind these two terms. Sampāra actually translates more directly as "continuous flowing," "continuous movement," or "keeping going." ${ }^{26}$ In Buddhism, it refers to a continuous cycle of birth (jāti), subsequent decay and death (jarāmarana). This cycle entails continuous suffering $(d u k k h a)$ and the only way to be liberated from it is through diligent spiritual practice. In cyclic existence, all things are subject to the laws of cause and effect, such that the quality of our actions (karma) determines a person's future destiny. Nirvāna, which literally translates as "extinguishing" or "cessation," is the antithesis of samsāra, and is the state where cause and effect no longer propels a person into a future rebirth beyond his or her control. 
In traditional Brahmanism, ätman is seen to be the subject which exists in samsāra. The Buddha however categorically rejected the metaphysical assumption of a 'soul' or 'self.' Buddhism accounts for the process of samssāra by appeal to phenomenological or psychological constituents. The person is seen as a stream of evolving consciousness. Since samsāra doesn't imply the transmigration of an essence or soul but instead follows the law of cause and effect, the transition from one life to another may be likened to the process where one billiard ball hits another billiard ball. The speed and direction of the second ball originates from the first. All things similarly arise from prior causes, and samsāra is uninterrupted cycle of birth and death. Strictly speaking, we can say that there is no rebirth but merely continuous births (and deaths). ${ }^{27}$

The seeming contradiction between rebirth and non-self can be solved by viewing the self as merely the temporary result of karmic formation. Think about the rise and fall of nations in history. For example, when the last Chinese empire - the Qing Dynasty - came to an end almost a century ago, the Republic of China was born. What is the relation between these two countries? Are they the same or are they entirely different? Is the Republic of China identical to the empire of Ching Dynasty? Or is it totally different from the empire?

We could say that the relation between a former nation and its current successor is analogous to a previous life and our current incarnation. ${ }^{28}$ We cannot say that they are exactly the same, nor can we claim them to be entirely different. Just as a sheet of paper is made from wood, we cannot claim the wood to be the paper, however there is a continuum that can be traced from the paper to the wood. Similarly boiled rice may have originated from uncooked rice, but it can neither be said to be entirely the same nor totally different to uncooked rice. Our existence within samsāra could perhaps be likened to these examples, whereby a mental continuum links one birth to the next. On the one hand, it would be incorrect to view a former life as being exactly identical to the present life, for that would entail an unchanging, permanent self or 'soul' which the Buddha rejected. Viewing them as two entirely separate entities on the other hand, would again cause one to fall into the trap of nihilism. It follows that a person who dies and is reborn elsewhere is neither the same person nor another. Although there is a continuum, which migrates from one life to the next, it is constantly changing and has no constant identity. Hence, no permanent self can be asserted. This, however, does not mean that karma is invalid because there is no self who will experience the fruits of previous actions. Every thought, word and deed leaves an imprint on our consciousness, and is carried over as potentials into the next life through a continuum. Hence the Buddhist concept of samsära, distinguished from the theory of reincarnation or transmigration that insist on the existence of an eternal soul, doesn't presuppose an unchanging and substantial being and thereby fall prey to the dangers of grasping an immortal self. With ignorance as the prime condition, the karma has come to be, and as long as the karmic force of ignorance survives, there will be "rebirth." That is, it is the karmic energy inherent in the conditions that creates continuity. In this continuous process there is no complete identity or diversity, and in every phase of assimilation there is an irreducible remainder of diversity making for dissimilation, and in every phase of dissimilation there is an irreducible remainder of identity making for assimilation. $^{29}$

The Buddhist theory of samsära therefore excludes sameness of the ego-identity of a transmigrating soul and also eliminates absolute diversity between the former and the 
subsequent existences. Herein lies the essence of the Middle-Way and Dependent Origination: avoiding both the extremes of eternalism and nihilism while remaining on the middle path. The basic tenets of Buddhism, such as impermanence and selflessness, don't run aground on the concept of rebirth/ sampsāra. Within the frame of a proper understanding of the Buddhist doctrine of non-self and rebirth, it seems difficult to agree that rebirth encourages us to conceive of our lives in strictly individual terms and devoid of a collective destiny. In Buddhist theory, individual-karma (ävenika-karma) is the karma belonging to a specific individual, while common-karma (sädhäraṇa-karma), is the karma shared through communal destiny. While karma can be conceived both individually and collectively, the Buddhist understanding of karma does not emphasize one over the other. ${ }^{30}$

In sum, samsāra is not only consistent with, but indeed follows from the Buddhist concept of selflessness and impermanence. While the naturalist views rebirth as violating elementary Buddhist doctrines such as non-self, I intend to show that an understanding of karma without rebirth as an inherent feature of sampsära, is incoherent with the core teachings of Buddhism. ${ }^{31}$

\section{Could karma with rebirth discourage positive action?}

Naturalists claim that the acceptance of rebirth encourages us to ignore issues of justice in this present life on the grounds of speculation about past and future lives and the view that the Buddhist theory of karma supports social passivity or acquiescence in the face of oppression. ${ }^{32}$ But it is in fact a false interpretation of Buddhism as merely a form of fatalism, pessimism, negativism or selfish egoism.

If we were to put aside the theory of compassion - one of the central teachings of the Mahayana tradition - and merely act out of self-interest, the Buddhist doctrine of karma and rebirth would still necessitate concern for beings who are experiencing suffering. Indeed, it is precisely because of cause and effect and the link between karma and rebirth that Buddhist practitioners strive to treat others with fairness. To take Wright's childabuse scenario as an example, ${ }^{33}$ if I don't wish to be born into a family where I might be severely abused, I ought to save a child from such dire circumstances in this present life. Similarly, if I don't wish to be poor in my future life, I should endeavor to better the condition of the poor and needy in my present life. On the other hand, if I currently happen to be poor, I will have to create the causes that will eventuate in wealth in order to change my fate. Therefore, although what we are is what we had been, we should remember what we will be is what we do now. According to the doctrines of karma and rebirth, we may know our past actions through examining our present condition, but we may also shape our future condition through our present action. The way to attain a better existence in future is through diligent practice in the present.

It is thus hard for one to believe that the teaching of rebirth encourages people to neglect justice and simply take a passive standpoint. Bramanic interpretation of rebirth may well discourage positive action and indoctrinate the legitimacy of 'caste' system. But this however, is not applicable to the Buddhist notion of rebirth. Sakyamuni Buddha criticized 'caste' as an institution and suggested that all human beings are equal. Thus a true Buddhist practitioner strives for justice and equality and very much emphasizes the development of deep concern for beings who experience suffering. If one were to merely watch 
on while another is being abused and defend one's passivism by arguing that this sort of treatment is just retribution for past sins, it would be a fatalist standpoint rather than a Buddhist one. To the contrary, a Buddhist practitioner would very much be motivated by the teachings of karma and rebirth to act in such a way as to relieve the predicament of any being who is experiencing suffering.

\section{On rebirth and the ilncentive of external rewards}

One of the reasons why naturalists suggest that rebirth ought to be separated from karma is because they hold that rebirth encourages the pursuit of external rewards such as wealth and status in a future life, rather than on the development of character in the present life. ${ }^{34}$ Such a claim however neglects morality and the independent thoughts of those who believe in rebirth, by confining their concerns to external rewards. According to Lawrence Kohlberg's (1927 1987) theory of moral development, the earliest stage in which a person becomes capable of moral consideration is childhood, which Kohlberg terms the "pre-conventional level." ${ }^{\text {35 }}$ One of the characteristics of this level of morality is defining 'right' and 'wrong' in terms of what results from actions in terms of rewards and punishments. Thus, parents often motivate their children to act in accordance with their wishes by proverbially 'dangling the carrot before the donkey'.

Although external rewards may well in some cases motivate certain types of behavior in Buddhist culture, a blanket statement such as 'all those who believe in karma and rebirth pursue external rewards', simply does not hold true. In Mahayana Buddhism, the so-called "bodhisattvas" forsake benefit to self by devoting themselves to work for the well-being of all living beings life after life and to nurture a virtuous character over numerous lifetimes. A fortunate rebirth is not to be pursued as an end in itself, but as a means to enable a practitioner to engage in further virtue for the benefit of others. As such, the accumulation of positive potential through the practice of giving in this life for example, which could manifest in a future life as material welfare, is part of the selfless motivation to benefit others and is a necessary component of realizing Buddhahood.

According to Mahayana texts, great bodhisattvas always resolve to be reborn again and again and even vow to be reborn in hell so that they may continuously save beings until such time as the entire realm of hell has been emptied. ${ }^{36}$ So, instead of focusing all hope on external rewards in a future life, the main concern of a bodhisattva is always to lessen the suffering of beings. One of the key conditions for them to be able to pursue this ideal, is the notion of afterlives. That is, the ambition is too great to reach in the short space of a single lifetime. Rebirth is therefore a necessary precondition to perfect the aggregation of internal virtues and eliminate all faults in order to reach Buddhahood. Multiple lifetimes are therefore justified in the context of Mahayana Buddhism.

This shows that the development of inner virtues is very much in accordance with the doctrine of rebirth. Even if we accept, as Wright suggests, that the rewards internal to that act of kindness are directly related to the act and are not contingent on anything but the act, ${ }^{37}$ the doctrine of rebirth still holds and remains inseparable from karma. This is because the bodhisattva seeks to be reborn in order to liberate beings from suffering. Thus, the claim that a good or right act, instead of giving rise to external goods, gives rise to the transformation in character that makes us virtuous does not preclude the theory of rebirth. No inconsistency exists between cultivation of inner 
virtue and the doctrine of rebirth. On the contrary, from the viewpoint of Mahayana, the perfect cultivation of virtue has presupposed the existence of rebirth. ${ }^{38}$

It should also be noted that there is no sharp distinction between external and internal rewards. A virtuous person, who already holds virtue as his own reward, is inclined to have and should further pursue external rewards. Though often the reward is contingent, there is some measure of certainty involved. External rewards could be employed as a substantial aid in benefiting others. That is, if the pursuit of external rewards is helpful to spiritual practice and enables one to engage in further virtue by benefiting other, then such a pursuit is by no means contrary to the aims of one who is acting from a moral standpoint. ${ }^{39}$ What is of the essence here is the practitioner's intent. If he were to pursue external rewards for his own gratification, his actions would not be virtuous. If, on the other hand, he pursues external rewards with the intention to utilize such gains in order to benefit others, the actions would be classified as virtuous and do not constitute a vice.

Although ordinary beings are motivated by external rewards, the doctrine of rebirth still has the function of edification as it encourages practitioners to pursue virtue and abandon wrongdoing. Just as parents may promise rewards or threaten with punishment to persuade a child to do one thing and abstain from another, so too practitioners of lesser capacity are encouraged to accumulate positive potential for their own benefit. The means itself is not the end, but may indeed lead to a good result. In this sense, rebirth has its function and is valuable for moral education or exhortation to urge virtuous behavior. The notion of temporary expedience (upāya) is also noteworthy as a means often employed by Buddhist teachers to develop the capacity of beginners on the path. Therefore, the Dalai Lama's assertion that one will lack material wealth as a result of stealing, doesn't mean, as Wright problematically asserts, that the Dalai Lama is primarily interested in external reward, ${ }^{40}$ because from the viewpoint of a certain scope of practitioner, awareness of the possible benefits or punishments related to our actions is an important component of spiritual development.

One way to distinguish external rewards from internal ones is by means of the difference between autonomy and heteronomy. ${ }^{41}$ Once an act is for the sake of pursuing external rewards, it is heteronomous and is to be discouraged, because only the autonomous acts are rewarded for internal goodness. All moral actions should, strictly speaking, be autonomous. Now the question arises whether or not the doctrine of rebirth compels us to act heteronomously. For some the answer is yes, for others no. It cannot be denied that some people may use Buddhist practices to achieve worldly aims, yet that does not take anything away from devoted practitioners with pure motivation who act autonomously and disregard personal reward. True bodhisattvas would never be concerned with their personal reward, whether such rewards be internal or external, for that would be contrary to their aims and as such would only serve to delay their spiritual progress. The Mahayana Buddhist's practice of morality or virtue is for its own good, and once they perform good or right action for the sake of pursuing virtues, paradoxically those actions won't be virtuous anymore.

\section{How the Buddhist concept of rebirth could contribute to ethical reflection}

While trying to articulate a naturalized concept of karma for contemporary ethics, a naturalist may doubt the advisability of linking up the doctrine of karma with rebirth 
by claiming that rebirth stands in the way of our understanding karma in purely ethical terms. ${ }^{42}$ But, is the concept of rebirth really irrelevant to contemporary ethics? Is the notion of rebirth entirely incompatible with common expectation or moral thinking?

Ancient Greek philosophers like Pythagoras (585 497 BC) and Plato (427 347 BC) already suggested the possibility of life after death and as well as transmigration or immortality. ${ }^{43}$ Immanuel Kant $(1724 \sim 1804)$ similarly proposed a theory of the afterlife within the framework of ethics. Kant claimed that the consequence of our limitation of knowledge rules out virtually all the belief of the existence of God, the immortality of soul and the freedom of will. This implies neither one of these three can be resolved by any appeal to pure reason or possible experience, but can only be viewed as 'postulates. ${ }^{44}$ But, Kant's ethics involves an ultimate end at which all action is directed. This end, defined as the "highest good", provides the basis for his moral argument for God and immortality as postulates of practical reason. The basic idea is that, since a just apportionment of happiness to virtue is inconceivable according to the laws of nature, we are constrained to assume the reality of immortality and a noumenal ground, that is, God, as its guarantee. Here we can see the postulations, such as immortality, are not unacceptable in an ethical theory. ${ }^{45}$

The reasoning behind Kant's three postulates can be said to correspond to the Buddhist viewpoint in the manner shown in Fig. 1 below.

Kant believes that we have the necessary free will to lead a conscientious life, even though we may not realize justice in this present life, the soul is immortal and we will receive due feedback in the future from God who acts as the arbitrator of fairness. Similarly, according to the basic mechanism of the Twelve Causal Links, ${ }^{46}$ mental consciousness deluded with ignorance, anger and greed causes the creation of undesirable karma through volition. Because this karma has to be experienced in future lives until it becomes exhausted, it leads to a continuous cycle of birth and death also known as samsāra.

As previously mentioned, Buddhism not only adopts rebirth on the grounds that we must assume a continuum of lives in order to account for the rewards of the virtuous and the punishments of the wicked, but also sees rebirth as necessary in order to conceive of the possibility of the attainment of the virtuous perfection which bodhisattvas strive for, yet may not be attainable in this present life. This is somewhat similar to Kant's justification for the immortality of the soul. Kant asserts that for the sake of guaranteeing the moral perfection commanded by the "categorical imperative," the soul has to be immortal. Furthermore, according to Kant's ethics, God, immortality, and free will must be assumed as conditions of the full realization of the goals of morality, though he does not offer us an experiential proof but merely appeals to the principle of the "primacy of practical reason." 47 The Buddhist concept of rebirth is therefore not

\begin{tabular}{|c|c|}
\hline Kant's Ethics & Buddhist Ethics \\
\hline Free Will & Volition $($ Cetanā $)$ \\
\hline Existence of God & Karma \\
\hline Immortality of Soul & Rebirth (Sams $\bar{a} r a)$ \\
\hline
\end{tabular}


only plausible, but also very much relevant in reference to Kant's moral philosophy and modern-day ethical reflection.

Also, to those who feel life may be too short to fulfill all hopes and realize all enjoyments, the idea of rebirth presents some hope. Bertrand Russell (1872 1970), for example noted in his autobiography the reasons he had lived for, and concluded:

This has been my life. I have found it worth living, and would gladly live it again if the chance were offered me. ${ }^{48}$

Russell's words may be more sentimental than logical, yet alludes to the thought that living merely one life does not enough. The thought of an afterlife, or more than one life, is therefore not an uncommon expectation.

In sum, a view of karma without rebirth may have a role to play in contemporary ethical reflection, yet this does not mean that rebirth presents an obstacle to understanding karma in purely ethical terms. Nor does it mean that we have to forsake rebirth in order to develop a naturalized concept of Buddhist karma so as to render it more relevant to contemporary ethical reflection. There may be two different frameworks to interpret karma in Buddhism, yet both approaches agree on the existence of rebirth. While the Theravadins place greater emphasis on their own liberation in present or future lives, practitioners of Mahayana Buddhism are more advanced in scope and thus have higher aims. Such practitioners take external rewards merely as a means to an end. The view of rebirth that the naturalists are opposed to pertains more to the Theravadin perspective, where individual destiny takes precedence over collective destiny. Within the Mahayana framework, numerous births offer the hope of achieving the ultimate goal in future, if unattainable in the present life. For those who strive to develop wisdom and compassion, the doctrine of rebirth has great import. Rebirth allows the bodhisattva to assume the heavy responsibility of liberating uncountable beings from suffering life after life. This is because the goal of a bodhisattva is not merely to treat others fairly, but to save all beings without exception from the ocean of suffering and lead them towards enlightenment. ${ }^{49}$

\section{Conclusion}

The naturalistic interpretation of theory of karma seems to reveal a certain cultural incompatibility between Western scientific views and Eastern philosophy. Rebirth might be seen as a metaphysical hypothesis from scientific point of view, but in Asia rebirth is viewed as a natural phenomenon that governs the existence of all life in the universe. Put differently, the laws of rebirth and karma are more of a subjective realization than a theoretical speculation to be tested and proven or disproven by scientific means. A naturalized concept of karma, therefore, can only be conceived of in a Western cultural setting. I believe that this cultural gap is closely related to the debate between materialism as viewed from scientific perspective and idealism as seen from a spiritual perspective.

My main intent is not to prove the existence of rebirth with this essay, but rather to ask if rebirth is really irrelevant to ethical reflection. It is a common belief that we live in a morally ordered universe and intuitively sense the workings of a principle of moral justice which regulates the course of events in such a way that good and bad actions 
are somehow accounted for to ensure fairness and maintain overall balance. Many would argue that this demand for moral justice is more than just a psychological expectation or mental fabrication. So does the Buddhist point of view. Though the historical Buddha did not found his system of ethics on the theory of rebirth and one does not need to adhere to this doctrine in order to be a Buddhist, ${ }^{50}$ gaining an understanding of both the workings of karma and rebirth is encouraged in Buddhist texts in order to encourage virtuous behavior. Our main motivation to live morally is not merely for the sake of good rewards in a future life, but an acceptance of the teaching could serve to reinforce our commitment to moral discipline in this present life as well. This implies our efforts will be not in vain but eventually we will receive the deserved fate either in the present or in the future. ${ }^{51}$

Actually, the value of the concept of rebirth in ethical terms is dependent upon the interpretation we chose to employ. For instance, Buddhist scholar Peter Harvey suggests that rebirth ought to be seen both as a process which takes place after death and also as a process taking place throughout life. Since we are constantly undergoing change over the progression of a lifetime, he believes that we are in a sense constantly 'reborn' as a 'different' person according to our various moods, and we may experience 'heavenly' or 'hellish' states of mind depending on how we think and act. This continuous process of change, determined by the nature of our actions, does not abruptly stop at death but carries on. ${ }^{52}$

Thus, the Middle Way stance requires that we neither cling to concepts rigidly nor dismiss them entirely. This allows the Buddhist practitioner to be flexible and use discerning wisdom to continuously advance on the spiritual path. Bearing in mind that the central purpose of Buddhism is to pursue the cessation of suffering and achieve liberation from saṃsāra, we need to constantly examine whether the traditional Buddhist teachings serves this purpose. ${ }^{53}$ But over and beyond one's personal aims of achieving liberation, the altruistic spirit of the Mahayana is particularly noteworthy and should not be overlooked in explorations dealing with karma and rebirth. That is, for the sake of everlasting practice to attain perfect realization, as the ideal of bodhisattvas, the postulation of rebirth is beneficial in that it encourages compassionate behavior and a deeper regard for those who are in need, supplying a long-term perspective for facilitating one's ethical growing and enhancing spiritual development.

\section{Endnotes}

1. During the time that Indian Buddhism was disseminated in China, philosophy in China had been through a long history of integration and confliction. Generally speaking, traditional Chinese culture is more practical and concerned about affairs of the present life, which explains why the Chinese place so much emphasis on the importance of filial piety and the relations among various generations. It can perhaps be said that people in India are generally more concerned about the affairs pertaining to the afterlife, hence Indian spiritual practitioners are mainly concerned with matters of liberation from the suffering of this world.

2. See Zürcher (2007) for more on this topic.

3. Kaufman (2005).

4. These discussions on karma can be found in the Journal of Buddhist Ethics, Volume 12, 2005. 
5. Winston L. King for example supports the separability of karma and rebirth, concluding that "a doctrine of karmic Rebirth is not essential to a viable and authentic Buddhist ethic in the West," King (1994). For more on this topic, see also Wright (2005).

6. Flanagan writes: "Imagine Buddhism without rebirth and without a karmic system that guarantees justice ultimately will be served, without nirvana, without bodhisattvas flying on lotus leaves, without Buddha worlds, without nonphysical states of mind, without any deities, without heaven and hell realms, without oracles, and without lamas who are reincarnations of lamas. What would be left? My answer is that what would remain would be an interesting and defensible philosophical theory with a metaphysics, a theory about what there is and how it is, an epistemology, a theory about how we come to know what we can know, and an ethics, a theory about virtue and vice and how best to live. This philosophical theory is worthy of attention by analytical philosophers and scientific naturalists because it is deep." Flanagan (2011), p3.

7. Batchelor (1998), and Batchelor (2011).

8. Willson (1987); Thanissaro (2013); Bodhi (2010); Bodhi (2013).

9. Wright (2005). http://blogs.dickinson.edu/buddhistethics/files/2011/01/wright01.pdf

10. Dale Wright claims: "The primary reason that karma is a promising ethical concept for us today is that it appears to propose a natural connection between a human act and its appropriate consequence, or, in traditional terms, between sin and suffering, virtue and reward. The connection requires no supernatural intervention: we suffer or succeed because of the natural outcome of our actions themselves, rather than through the subsequent intervention of divine punishment or reward. Moral errors contain their own penalties as natural consequences, and every virtue encompasses its own reward." Wright (2005), p.79. Wright further notes: “Throughout Asia, karma defines the ethical dimension of culture and remains the key to understanding Buddhist morality. Karma is the teaching that tells practitioners that it matters what they do throughout their lives, and how they do it. It articulates a close relationship between what one chooses to do and who or what that person becomes over time. The extraordinary sophistication of this early concept should, in fact, be counted as one of the most significant achievements of South Asian culture, and an impressive gift to contemporary ethical thinking globally.” Wright (2005), p.79.

11. Wright (2005), p.83.

12. For instance, to Tibetans the idea of rebirth and the system of reincarnated lamas are inseparable and irrefutable, not only in religious terms but in daily life as well.

13. For example, a number of scholars have made great efforts to study memory of previous lives to support the theory of rebirth. See Stevenson (1980) and (Stevenson (2000)); Story (2003); and Tucker (2008).

14. Experience is not always as reliable as modern Rationalism claims. Descartes, for instance, points out while physical objects do exist, they may not at all exist in a way that exactly corresponds to our sensory interpretation of them.

15. I mention this in order to respond to Wright's claim that "As it is traditionally conceived in Asia, karma requires the metaphysical doctrine of rebirth to support its often counter-experiential claims about the ultimate triumph of cosmic justice for the individual." Wright (2005), p.81.

16. Jinpa (2003), p.77. 
17. Dalai Lama says, "If I look for something and fail to find it, this does not mean that the thing I am seeking does not exist. Not seeing a thing is not the same as seeing its non-existence." Dalai (2005), p. 35.

18. Buddhism asserts that the human condition is full of misery and pain. Our immediate duty, therefore, is to get rid of this misery and pain. If we bother with meaningless metaphysical speculation, we behave like the foolish man who was hit by a poisonous arrow and yet wasted his time on futile speculation about the origin, the size, the metal, the maker and the shooter of the arrow, rather than focusing his efforts on removing the arrow.

19. Thanissaro (2013).

20. Moore (1903).

21. Pidgen (2010).

22. Harvey suggests that the Buddha's teaching of Conditioned-Arising gives a justification for rebirth. He notes: "Conditioned Arising here provides a 'middle' way of understanding which avoids the extremes of 'eternalism' and 'annihilationism': the survival of an eternal Self, or the total annihilation of a person at death. Harvey (2013), p. 69. For similar ideas, see also Gethin (1998), p. 145.

23. This does not necessarily mean, however, that accepting rebirth is a necessary condition for becoming a Buddhist. That is, one who doesn't believe in rebirth could still be a faithful Buddhist. One of the most important conditions of being considered a Buddhist, is to understand the workings of Dependent Arising and the views of the Middle-Way philosophy. Since a view of karma without rebirth seems to violate these aspects of Buddhism, and causes one to adopt the erroneous view of annihilation, denying rebirth cannot be considered a plausible approach.

24. See Nagapriya, (2012) for a more detailed discussion.

25. As Wright says, "Wherever in Buddhist thought rebirth is given a strong and substantial role, no self and other dimensions of the teachings are reduced in significance. Wherever the teaching of no self and related doctrinal elements are given strong and consistent application, very little is left that rebirth could mean.” Wright (2005), p.88.

26. Gombrich (2009), p. 33.

27. Renowned Thai monk Buddhadasa Bhikkhu wrote an article Anattā E Rebirth on this subject which was spread widely on the internet. As Buddhadasa says, the rebirth of the same person does not occur. But the birth of different things is happening all the time. It happens often and continuously, but there is no rebirth. There is no such thing in reality as rebirth or reincarnation. If all is anattā, there is nothing to get reborn. Unless we make spiritual progress and gain realizations, there is only birth, birth, birth, birth... and so on ad infinitum. That means that birth is happening all the time, but it is never the same person being born a second time. Every birth is new, so it is not entirely correct to refer to this process as "rebirth" or "reincarnation."

28. Lin (2013), p.246.

29. Thera (1998), pp.43 45 .

30. I mention this in order to respond to Wright's claim that "Rebirth encourages us to conceive of our lives in strictly individual terms, as a personal continuum through many lives, rather than collectively, where individuals share in a communal destiny, contributing their lives and efforts to that collective destiny." Wright (2005), p.89.

31. Actually there are similar efforts to legitimate the ideas of karma and rebirth, not wholly incompatible with naturalism but not reducible to it, as a helpful system of 
spiritual ethics. For instance, Joseph Loizzo suggests there is a role in contemporary philosophy and psychology for an intergenerational theory of human agency informed by the Buddhist theory of karma. He provides new interpretations of karma in light of psychological naturalism, and raises the idea that the rebirth of self as neither same nor different is descriptive of the natural process of intergenerational inheritance of habit patterns in the course of parentings and early development. The model of intergenerational agency he suggested is based on a comparative study of ordinary language philosophy in ancient India and the contemporary West. Its premise is that most theories of moral development and psychological agency are limited by the insistence on a substantial or essential ground for the designation of a person or self. Ordinary language philosophy offers greater conceptual freedom because it accepts a distinctively human theory of self as a linguistic construction that refers to mind/body systems and elements in which there is no substantial or essential self. This conceptual freedom permits a model of human agency as an open system of linguistic reference that can be transmitted across generations in the course of language acquisition. For further discussion on this topic, please see Loizzo (2011).

32. Wright (2005), p.81.

33. Dale Wright notes: "For example, if you believe that a child being severely abused by his family is now receiving just reward for his past sins, you may find insufficient reason to intervene even when that abuse appears to be destructive to the individual child and to the society." Wright (2005), p. 81.

34. Wright (2005), pp.82-85.

35. Nevid (2009), p.371.

36. One of the vows of Ksitigarbha Bodhisattva states: "If the hell is not empty, I swear not to reach the Buddhahood. Only when all suffering beings have been liberated, will the time of my realization of Bodhi come."

37. Wright (2005), p. 82.

38. Chinese monk-scholar Ven. Yinshun $(1906 \sim 2005)$ cited the viewpoint from Mahäprajnäpäramitāsāstra when he wrote the following verse, "Lower people give for the sake of themselves. Middle people give for their own liberation. Those who give all for the benefit of others are called great people." Shi (1998), p228. Although practitioners of lesser capacity strive toward virtue out of utilitarian motivation, this is not inherently wrong from a Buddhist perspective, as it helps them to achieve the necessary material resources in a future life to refine and develop their practice. A great practitioner however resolves to attain enlightenment for the sake of all beings without exception. The altruistic motivation of a bodhisattva obviously shows that the doctrine of rebirth does not merely encourage pursuit of external rewards for our actions.

39. If we were to articulate an ethical system that does not reward virtuous behavior, the impetus to cultivate virtue would be lost, even though such cultivation might help shape our character and determine who we are. Put differently, one of the ways to justify the actual gatherings of internal rewards is precisely by means of the outcomes of external rewards. It seems to me that the reason that external reward is contingent is because it is only a means to an end. This means, however, could be instrumental in the development of a virtuous character.

40. Wright (2005), p. 83.

41. A key notion in Immanuel Kant's moral philosophy is that of 'autonomy', understood as one capacity of the will to legislate to itself. Kant believes that autonomy is the 
ground of the dignity of human nature and of every rational being. A moral agent is autonomous if his will is not determined by external factors and if the agent can apply laws to himself or herself in accordance with reason alone. If we autonomously recognize a moral value, and make it our own, we are acting as we have most deeply and freely resolved to act. For more on this topic, please see Sensen (2013).

42. Wright (2005), p.89.

43. Russell (1946), p.50 and pp.147-156; and also Obeyesekere (2002).

44. Guyer (2000), p.90.

45. For more on this topic, see Guyer (2000), pp. 350-357.

46. The twelve causal links explain the continuation of the cycle of suffering and rebirth (sampāra) in great detail, describing how each causal factor gives rise to the next. In order of succession, they are: ignorance (avidyā), formations (saṃskāras), consciousness (vijñāna), name and form (nämarūpa), the six sense bases (saḍayatana), contact (sparśa), feeling (vedanā), thirst (trșṇa)), clinging (upādāna), existence (bhava), birth (jāti), old age and death (jarā-marana). For more on this topic, see Harvey (2013), pp. 65-67.

47. Guyer (2000), p.69 and pp.333-371.

48. Quoted from the prologue of Bertrand Russell's autobiography available at: http:// www.users.drew.edu/ jlenz/br-prolog.html

49. There is a well-known verse that has long been a source of inspiration written by Santideva in the 8th Century, "For as long as space endures and for as long as the world lasts, may I live dispelling the miseries of the world." Sāntideva et al. (1997)), p. 155. This verse clearly expresses the noble aspiration of a bodhisattva to remain in this world in order to work for the welfare of sentient beings.

50. See Keown (2000), p.43.

51. Peter Harvey holds similar opinion, as he says, "Working with a rebirth perspective also helps sustain a long-term motivation for moral and spiritual practice. While death means that one loses all physical possessions, and is parted from one's loved ones and one's life's 'attainments', the purification of character that is developed by ethical and meditative practice is seen as something that death does not destroy. It becomes part of one's mental continuum that will'spill over'into another life. In that life, the spiritual development of this life may be neglected or further built on: but at the very least, it can act as a positive residue of this life, to be used as a foundation for further development. The opposite applies in the case of bad character-traits." Harvey (2000), p.29.

52. Harvey (2013), p.47. Hence Buddhism might recognize rebirth as representations of our mental states that correlate to six (or in certain cases ten) distinct realms of existence. These distinct realms are understood to originate from mental propensities. When greed arises in the mind, it is no different to that of a pig, because at this time, our mental propensity is comparable to the propensity of a gluttonous pig. Any number of mental states can potentially arise during the course of a day, and with the change of one mental state to the next at times happening almost instantaneously, it can be argued that we are reborn almost every moment. As long as there is greed, aversion, and delusion, and as long as desires and ignorance are not extinguished, we continuously create karma and experience rebirths. From this perspective, it can be said that rebirth and karma aren't entirely based on religious principles, but can perhaps also be understood in purely ethical terms. This interpretation of Buddhist karma as a 
psychological system of ethics seems to be a rather popular notion. For more please refer to Loizzo (2011).

53. For similar approach, please see Nagapriya (2012)).

\section{Competing interests}

The authors declare that they have no competing interests.

\section{Authors' information}

Chien-Te Lin, Ph. D. is Associate Professor of Religion and Humanity at Tzu-Chi University in Hualien, Taiwan. He specializes in research pertaining to Eastern philosophy, particularly Buddhism and Taoism. Recently he has endeavored to apply Eastern thoughts to contemporary philosophical topics, including the mind-body problem, consciousness, and some moral issues. He also publishes papers on the Buddhist philosophy of Master Yinshun. Email: bhadanta@gmail.com Wei-Hung, Yen, Ph.D is Assistant Professor of Philosophy Department at Tunghai University in Taichung, Taiwan. He specializes in research pertaining to Buddhist philosophy and Chinese Philosophy, particularly Buddhist Ethics, Madhyamika philosophy in China, and the philosophies of the Wei and Jin Dynasties. Recently he has endeavored to apply the insights of Chinese Buddhism to discussions related to contemporary ethical issues. Email: philoweihung@gmail.com

\section{Authors' contributions}

CT Lin wrote the first draft of this manuscript and approved the production proofs. WH Yen participated in the discussion of this study, and collated the drafts of this manuscript. Both authors read and approved the final manuscript.

\section{Author details}

${ }^{1}$ Institute of Religion and Humanity, Buddhist Tzu Chi University, 67 St. Jiren, 970 Hualien, Taiwan. ${ }^{2}$ Department of Philosophy, Tunghai University, No.1727, Sec.4, Taiwan Boulevard, Xitun District, 40704 Taichung, Taiwan.

Received: 2 July 2014 Accepted: 26 February 2015

Published online: 09 June 2015

\section{References}

Batchelor, Stephen. 1998. Buddhism without beliefs: a contemporary guide to awakening. Riverhead: Trade. Batchelor, Stephen. 2011. Confessions of a Buddhist Atheist. Spiegel \&: Grau.

Bodhi, Bhikkhu. 2010. "Dhamma Without Rebirth?" Access to Insight Legacy Edition http://www.accesstoinsight.org/lib/ authors/bodhi/bps-essay_06.html.

Bodhi, Bhikkhu. 2013. "Does Rebirth Make Sense?" Access to Insight Legacy Edition http://www.accesstoinsight.org/lib/ authors/bodhi/bps-essay_46.html.

Dalai, Lama. 2005. The universe in a single atom: the convergence of science and spirituality. New York: Three River Press. Flanagan, Owen. 2011. The Bodhisattva's Brain: Buddhism Naturalized, Cambridge, Mass.: the MIT Press.

Gethin, Rupert. 1998. The Foundations of Buddhism. Oxford: Oxford University Press.

Gombrich, Richard F. 2009. What the Buddha Thought. London: Equinox Publishing Ltd.

Guyer, Paul. 2000. Kant on freedom, law, and happiness. Cambridge: Cambridge University Press.

Harvey, Peter. 2000. An introduction to Buddhist ethics: foundations, values and issues. Cambridge: Cambridge University Press.

Harvey, Peter. 2013. An introduction to Buddhism: teachings, history and practices. Cambridge: Cambridge University Press. Jinpa, T. 2003. Science as an ally or a rival philosophy: Tibetan buddhist thinkers' engagement with modern science. In Buddhism and science: breaking new ground, ed. A Wallace. New York: Columbia University Press.

Kaufman, Whitley. 2005. Karma, rebirth, and the problem of evil. Philosophy East and West 55(1): 15-32.

Keown, Damien. 2000. Buddhism: a very short introduction. Oxford: Oxford University Press.

King, Winston L. 1994. "A Buddhist Ethic Without Karmic Rebirth," in the Journal of Buddhist Ethics, Volume 1. http://blogs.dickinson.edu/buddhistethics/tag/rebirth/

Lin, Chien-Te. 2013. "Rethinking mind-body dualism: a Buddhist take on the mind-body problem.". Contemporary Buddhism 14(2): 239-264.

Loizzo, Joseph. 2011. Personal agency across generations: evolutionary psychology or religious belief. Sophia 50: 429-452

Moore, George Edward. 1903. Principia Ethica. Cambridge: Cambridge University Press.

Nevid, Jeffrey S. 2009. Psychology: concepts and applications. Connecticut: Cengage Learning.

Nagapriya. 2012. Exploring Karma and Rebirth, UK: Windhorse Publications Ltd.

Obeyesekere, Gananath. 2002. Imagining Karma: ethical transformation in Amerindian, Buddhist, and Greek rebirth. Berkeley: University of California Press.

Pidgen, Charles R. 2010. Hume on Is and Ought. New York: Palgrave Macmillan.

Russell, Bertrand. 1946. History of Western Philosophy. London: G. Allen.

Saantideva, Wallace, B Alan, and A Vesna (eds.). 1997. A Guide to the Bodhisattva Way of Life. New York: Snow Lion Publications.

Sensen, Oliver (ed.). 2013. Kant on moral autonomy. Cambridge: Cambridge University Press.

Shi, Yin-Shun. Trans. by Yeung, Wing. 1998. The Way to Buddhahood: Instructions from a Modern Chinese Master, Boston: Wisdom Publications.

Stevenson, lan. 1980. Twenty Cases Suggestive of Reincarnation. Virginia: University of Virginia Press.

Stevenson, lan. 2000. Children who remember previous lives: a question of reincarnation, McFarland \& Co Inc Pub.

Story, Francis. 2003. Rebirth as doctrine and experience: essays and case studies. Sri Lanka: Buddhist Publication Society. 
Thanissaro, Bhikkhu. 2013. "The Truth of Rebirth: And Why it Matters for Buddhist Practice", Access to Insight Legacy Edition http://www.accesstoinsight.org/lib/authors/thanissaro/truth_of_rebirth.html

Thera, Nyanaponika. 1998. Abhidhamma studies: Buddhist explorations of consciousness and time. Boston: Wisdom. Tucker, Jim B. 2008. Life before life: children's memories of previous lives. New York: St. Martin's Griffin Press.

Willson, Martin. 1987. Rebirth and the Western Buddhist. London: Wisdom Publications.

Wright, Dale. 2005. "Critical Questions Towards a Naturalized Concept of Karma in Buddhism", in Journal of Buddhist Ethics, Volume 12, pp. 78-93. http://blogs.dickinson.edu/buddhistethics/files/2011/01/wright01.pdf

Zürcher, Erik. 2007. The Buddhist Conquest of China: The Spread and Adaptation of Buddhism in Early Medieval China. Leiden: Brill Academic Pub.

\section{Submit your manuscript to a SpringerOpen ${ }^{\circ}$ journal and benefit from:}

- Convenient online submission

- Rigorous peer review

- Immediate publication on acceptance

- Open access: articles freely available online

- High visibility within the field

Retaining the copyright to your article

Submit your next manuscript at $\gg$ springeropen.com 